\title{
Håndtering av seponeringsreaksjoner
}

\author{
Leger bør ha kjennskap til viktige seponeringsreaksjoner for å kunne \\ håndtere avslutning av legemiddelbehandling.
}

Se også kunnskapsprøve på www.tidsskriftet.no/quiz

\begin{abstract}
Jan Schjøtt
jan.didrik.schjott@helse-bergen.no Seksjon for klinisk farmakologi Laboratorium for klinisk biokjemi Haukeland universitetssykehus 5021 Bergen
\end{abstract}

Guttorm Raknes

Steigen legesenter

8283 Leinesfjord

Leger er ofte tilbakeholdne med å avslutte medikamentbehandling, selv om nytten av legemidlet er usikker og pasienten bruker mange legemidler samtidig, med økt risiko for interaksjoner. Dette kan skyldes respekt for behandling iverksatt av kolleger, frykt for forverring av grunnsykdom eller bekymring for forholdet til pasienten. Seponering er ofte mindre problematisk enn forventet og kan være assosiert med helsegevinst (1).

\section{Materiale og metode}

I denne artikkelen presenteres viktige seponeringsreaksjoner og strategier for å håndtere disse. Grunnlaget for artikkelen er ikkesystematiske litteratursøk i PubMed med et skjønnsmessig utvalg av artikler basert på forfatterenes erfaring innen feltet.

\section{Generelle momenter}

Problemer i forbindelse med seponering er i størst grad knyttet til legemidler som påvirker sentralnervesystemet og hjerte- og karapparatet (2). Mekanismene for slike reaksjoner er ufullstendig beskrevet, men endret cellulær signalformidling og forbigående forstyrrelse av homøostatisk kontroll er sannsynligvis involvert. Dette understøttes av at pasienter kan få en rekke autonome symptomer ved seponering (3). Det er et problem at disse symptomene kan forveksles med forverring av grunnsykdom, noe som făr leger til å reintrodusere medikamentet.

Bortsett fra ved akutte tilstander eller forgiftning bør man som regel seponere ett legemiddel om gangen for best å vurdere effekten. Risiko for reaksjoner ved seponering av legemidler er sparsomt beskrevet i litteraturen. De retningslinjer som foreligger, er basert på observasjonelle studier og anbefalinger fra eksperter, og er ofte begrenset til visse legemiddel- og pasientgrupper. Legemiddelkomiteen i Västerbottens län i Sverige har samlet og systematisert kunnskap om avslutning av legemiddelbruk i boken FAS-UT, som identifiserer fem hovedtyper av seponeringsreaksjoner ved avslutning av legemiddelbehandling (4). Ved seponering av et legemiddel kan én eller flere av disse være involvert.

\section{Reboundeffekter}

Bråseponering av enkelte legemidler kan føre til at symptomer man opprinnelig brukte legemidlet for, kommer tilbake i mer uttalt grad enn det som var utgangspunktet for behandlingen. Eksempler er forverret nesetetthet etter kronisk bruk av slimhinneavsvellende nesespray, blodtrykksstigning eller arytmi ved seponering av betablokker, og hodepine etter overforbruk av reseptfrie analgetika.

Reboundeffekter kan kategoriseres som fysiologiske reaksjoner på seponering (3). For eksempel vil protonpumpehemmere gi kompensatorisk økt gastrinproduksjon som vil stimulere til økt saltsyrenivå og risiko for dyspepsi i lang tid etter seponering (4). Adjuvant behandling med H2-reseptorantagonister eller antacida kan derfor være aktuelt etter langvarig behandling med protonpumpehemmere (4). Slike forbigående fysiologiske reaksjoner kan lett forveksles med forverring av grunnsykdom med unødvendig reintroduksjon av legemidlet som resultat. Overforbruk av legemidler mot angst og søvnløshet skyldes ofte at man ikke har klart å avslutte behandlingen pga. reboundeffekter.

\section{Seponeringssyndrom}

Seponeringssyndrom forveksles ofte med reboundeffekter, men her dominerer andre symptomer enn dem man i utgangspunktet bruker legemidlet mot. Autonome symptomer som svetting, svimmelhet og skjelving er typisk. Kardinaltegnet er at reintroduksjon av legemiddel eller beslektet forbindelse bedrer symptomene. Rask avslutning av behandling med selektive serotoninreopptakshemmere (SSRI-preparater) er forbundet med et seponeringssyndrom med svimmelhet, søvnproblemer, nervøsitet, kvalme og agitasjon (5).
Begrepet abstinens brukes vanligvis om symptomer som oppstår ved seponering av vanedannende lege- og rusmidler. Ved alkohol- og opioidabstinens dominerer klassisk seponeringssyndrom i tidlig fase. Det blir likevel feil å sette likhetstegn mellom seponeringssyndrom og abstinens, siden abstinensbegrepet også brukes om andre psykologiske og fysiologiske reaksjoner knyttet til avhengighet og reboundeffekter.

Seponeringssyndrom (og reboundeffekter) unngås best ved langsomt å trappe ned bruken av legemidlet, og samtidig informere pasienten grundig om hvilke plager seponering kan medføre. Prinsippet om å benytte et legemiddel med samme virkningsmekanisme, men med lengre halveringstid, kan redusere plagene fordi legemiddelkonsentrasjonen reduseres mer gradvis. Dette er noe av rasjonalet for at metadon og buprenorfin er velegnet for nedtrapping ved opioidavhengighet, fluoksetin ved nedtrapping av SSRIpreparater (5), og diazepam ved nedtrapping av benzodiazepiner. Ved uttalte plager kan det $\mathrm{i}$ enkelte tilfeller være aktuelt å bruke et adjuvant legemiddel for en periode for å redusere symptomene. Klonidin ved opioidnedtrapping og karbamazepin og antidepressiver ved seponering av benzodiazepiner er eksempler (6). Oppfølging fra for eksempel fastlege med ikke-medikamentelle tiltak med vekt på støtte og motivasjon er effektive og lite ressurskrevende tiltak som øker sjansen for å lykkes med nedtrapping (7).

Symptomer på iatrogen binyrebarksvikt etter avsluttet langvarig bruk av glukokortikoider antiinflammatorisk kan klassifiseres som et seponeringssyndrom (8). Langsom nedtrapping av glukokortikoider er indisert etter langvarig bruk, men paradoksalt nok er det ikke utført prospektive studier for å avklare hva som er et optimalt nedtrappingsre-

\section{Hovedbudskap}

- Forbigående reaksjoner som oppstår ved seponering, kan lett forveksles med forverring av grunnsykdom

- Seponeringssyndrom og reboundeffekter unngås best ved langsom nedtrapping eller overgang til preparater med lang halveringstid

- Kommunikasjon med og medvirkning fra pasienten er viktig for vellykket seponering 
Tabell 1 Reaksjoner på seponering av legemidler med forslag til håndtering

\begin{tabular}{|c|c|c|}
\hline Reaksjon & Eksempler på legemidler & Beskrivelse \\
\hline Reboundeffekter & $\begin{array}{l}\text { Avsvellende nesespray } \\
\text { Benzodiazepiner } \\
\text { Betablokkere } \\
\text { Protonpumpehemmere }\end{array}$ & Forverring av grunnsymptomer \\
\hline Seponeringssyndrom & $\begin{array}{l}\text { Etanol } \\
\text { Glukokortikoider } \\
\text { Opioider } \\
\text { SSRI-preparater }\end{array}$ & Nye symptomer oppstår \\
\hline \multirow[t]{2}{*}{ Opphevet interaksjonseffekt } & $\begin{array}{l}\text { Metabolismeinduktorer } \\
\text { (karbamazepin, fenytoin) }\end{array}$ & $\begin{array}{l}\text { Bivirkninger eller manglende } \\
\text { effekt av gjenværende legemidler }\end{array}$ \\
\hline & $\begin{array}{l}\text { Metabolismeinhibitorer } \\
\text { (erytromycin, verapamil) }\end{array}$ & \\
\hline Opphevet profylakse & $\begin{array}{l}\text { Acetylsalisylsyre } \\
\text { Antihypertensiver } \\
\text { Bisfosfonater } \\
\text { Statiner }\end{array}$ & $\begin{array}{l}\emptyset \text { kt risiko for hendelse (for } \\
\text { eksempel slag og brudd) }\end{array}$ \\
\hline Sykdommen kommer tilbake & $\begin{array}{l}\text { Antidepressiver } \\
\text { Antiepileptika } \\
\text { Antihypertensiver } \\
\text { Antipsykotika }\end{array}$ & Sykdommen kommer tilbake \\
\hline
\end{tabular}

Håndtering

Langsom nedtrapping, bruk om mulig tilsvarende legemiddel med lang halveringstid

Vurder adjuvant legemiddel under nedtrappingen

Informer pasienten om type og varighet av forventede reaksjoner

Doseendring av gjenværende legemiddel

Monitorering av klinisk effekt eller serumkonsentrasjon av gjenværende legemiddel

Vurder nytte mot risiko

Reduser risiko for hendelse med andre medikamentelle eller ikke-medikamentelle tiltak

Reintroduser legemiddel

Vurder annen behandling

gime. Ifølge Norsk legemiddelhåndbok kan hele dosen bråseponeres ved inntil sju dagers behandling, mens rask nedtrapping (50\% reduksjon daglig) er akseptabelt ved inntil 14 dagers bruk. Ved høydosert behandling over lengre tid, kan nedtrappingen ta mange måneder, typisk med 10-30\% reduksjon hver annen uke.

\section{Opphevet interaksjonseffekt}

Seponering av legemidler som øker (induserer) eller reduserer (inhiberer) eliminasjon av pasientens øvrige legemidler kan være problematisk. Ved avslutning av generelle metabolismeinduktorer som fenytoin, karbamazepin og rifampicin kan konsentrasjonen av legemidler som påvirkes etter noen dager, øke med påfølgende økt fare for bivirkninger. Motsatt vil utfasing av metabolismeinhibitorer kunne medføre at konsentrasjonen av andre legemidler faller til nivåer hvor man ikke lenger har terapeutisk effekt.

Ved seponering av induktorer kan dosereduksjon av gjenværende legemiddel være aktuelt, dersom inhibitorer tas bort kan man vurdere doseøkning. Overvåking av legemidlet som påvirkes er et annet tiltak, enten ved å følge serumkonsentrasjonen av legemidlet som påvirkes før og etter seponering, eller ved å følge tett kliniske eller fysiologiske responser. Warfarin er et eksempel på et medikament som er svært følsomt for interaksjoner med andre legemidler, og for pasienter som antikoaguleres vil intensivering av INR-monitorering i forbindelse med seponering av andre legemidler være aktuelt.

\section{Opphevet profylakse}

Store prospektive studier har gitt oss god kunnskap om hvilken risikoreduksjon for aterosklerotisk sykdom som kan oppnås ved bruk av blodtrykks- og kolesterolsenkende behandling som primærprofylakse. Vi vet mindre om hvordan risiko for slag eller hjerteinfarkt endrer seg når behandling med statiner eller antihypertensiver avsluttes på grunn av livsstilsintervensjon, slik som røykeslutt eller kostholdsomlegging. Seponering av blodplatehemmere er derimot dokumentert å øke risiko for sykdom (9). En studie viste at seponering av bisfosfonater etter fem års behandling ga ytterligere fem års beskyttelse mot fraktur (10).

I tilfeller hvor den oppnådde risikoreduksjonen av legemidler er liten, vil det ofte være riktig å seponere, særlig dersom pasienten opplever en reduksjon i livskvalitet som ikke står i samsvar med oppnådd risikoreduksjon.

\section{Sykdommen kommer tilbake}

Når legemidler seponeres, vil det i mange tilfeller være risiko for at sykdommen kommer tilbake uten at det dreier seg om en reboundeffekt. Dette gjelder særlig sykdommer med langtrukket forløp og risiko for komplikasjoner, og hvor vedlikeholdsbehandling er vanlig. Eksempler er hypertensjon eller kronisk psykisk lidelse. Tilfeller hvor flere tilstander behandles samtidig er kompliserte. For eksempel kan seponering av diuretika være vellykket $\mathrm{i}$ forhold til hypertensjon, men forverring av hjertesvikt kan føre til behov for reintroduksjon (11).

Dersom man velger å prøveseponere ved slike tilstander, er det viktig å informere pasienten om tegn på tilbakefall. Et alternativ til å gå tilbake til det opprinnelige regimet, er å vurdere om legemidlet kan benyttes i en lavere dose.

\section{Konklusjon}

I mange tilfeller vil helsegevinsten av å redusere medikamentell behandling langt overskride eventuelle problemer knyttet til seponering. Det er derfor viktig at frykt for seponeringsreaksjoner ikke fører til at pasienten fortsetter å bruke unødvendige legemidler. Forskrivning av preparater særlig assosiert med seponeringsreaksjoner bør om mulig unngås hvis det finnes mer egnede alternativer. I tabell 1 oppsummeres håndtering av de vanligste seponeringsreaksjonene.

Oppgitte interessekonflikter: Ingen

\section{Litteratur}

1. van der Velde N, Stricker BH, Pols HA et al. Risk of falls after withdrawal of fallrisk-increasing drugs: a prospective cohort study. Br J Clin Pharmacol 2007; 63: 232-7.

2. Graves T, Hanlon JT, Schmader KE et al. Adverse events after discontinuing medications in elderly outpatients. Arch Intern Med 1997; 157: 2205-10.

3. Coulson J, Routledge PA. Adverse reactions to drug withdrawal. Adverse Drug React Bull 2008; 252: $967-70$.

4. Lundgren C. FAS-UT. Råd vid utvärding och avslutning av läkemedelsbehandling. Klippan: Ljungbergs Tryckeri, 2005.

5. Castberg I. Seponeringssyndrom etter behandling med antidepressiver. Tidsskr Nor Lægeforen 2004 124: 2493-4

6. Lader M, Tylee A, Donoghue J. Withdrawing benzodiazepines in primary care. CNS Drugs 2009; 23: 19-34

7. Mouland G. Praktiske råd om nedtrapping av benzodiazepiner. Tidsskr Nor Lægeforen 2001; 121 : 2394-5.

8. Bain KT, Holmes HM, Beers MH et al. Discontinuing medications: a novel approach for revising the prescribing stage of the medication-use process. J Am Geriatr Soc 2008; 56: 1946-52.

9. Lordkipanidzé M, Diodati JG, Pharand C. Possibility of a rebound phenomenon following antiplatelet therapy withdrawal: a look at the clinical and pharmacological evidence. Pharmacol Ther 2009; 123: $178-86$

10. Black DM, Schwartz AV, Ensrud KE et al. Effects of continuing or stopping alendronate after 5 years of treatment: The Fracture Intervention Trial Longterm Extension (FLEX): a randomized trial. JAMA 2006; 296: 2927-38

11. Iyer S, Naganathan V, McLachlan AJ et al. Medication withdrawal trials in people aged 65 years and older: a systematic review. Drugs Aging 2008; 25 : $1021-31$ 